\title{
MEASUREMENT OF BIO-IMPEDANCE ON AN ISOLATED RAT SCIATIC NERVE OBTAINED WITH SPECIFIC CURRENT STIMULATING PULSES
}

\author{
MERITEV BIOIMPEDANCE NA IZOLIRANEM ŽIVCU \\ ISCHIADICUS PRI PODGANI, VZBUJENEM S POSEBNIMI \\ TOKOVNIMI STIMULACIJSKIMI IMPULZI
}

\author{
Janez Rozman'1,3, Monika C. Žužek², Robert Frangež², Samo Ribarič ${ }^{3}$ \\ ${ }^{1}$ Center for Implantable Technology and Sensors, ITIS d. o. o., Lepi pot 11, 1000 Ljubljana, Slovenia \\ 2Institute of Physiology, Pharmacology and Toxicology, Veterinary Faculty, University of Ljubljana, Gerbičeva 60, 1000 Ljubljana, Slovenia \\ ${ }^{3}$ Institute of Pathophysiology, University of Ljubljana, ZaMedical Faculty, loška 4, 1000 Ljubljana, Slovenia \\ samo.ribaric@mf.uni-lj.si
}

Prejem rokopisa - received: 2015-09-30; sprejem za objavo - accepted for publication: 2015-10-26

doi:10.17222/mit.2015.307

\begin{abstract}
In this study we designed and tested a four-probe, bio-impedance measurement set-up for peripheral nerves, based on the Red Pitaya open-source measurement and control tool. The set-up was tested on an isolated rat sciatic nerve (RSN) while it was stimulated with specific current stimulating pulses. The measurements tested the hypothesis that the specific waveform of a stimulating pulse elicits current differences at the double layer (DL) interface between the platinum (Pt) stimulating electrode and the nerve tissue. Impedance spectroscopy was used to electrically characterize the interface between the Pt electrode and the nerve tissue and measure the interface electrical impedance $(Z)$. An analysis of the frequency response and the impedance, with specific current stimulating pulses, characterised the structure and the composition-related electrical properties of the RSN. An analysis of the voltage responses (VRs), measured at the same time, showed that the maximum negative polarization across the electrode-electrolyte interface $\left(E_{\mathrm{mc}}\right)$ and the maximum positive polarization across the electrode-electrolyte interface $\left(E_{\mathrm{ma}}\right)$ did not exceed the safety limits for water electrolysis. We conclude that the voltage and current changes, elicited at the DL of the interface between the Pt stimulating electrode and the nerve tissue, do not lead to tissue damage. Based on the obtained electrophysiological results we conclude that the developed stimulating electrodes and the stimulus pattern could act as a useful tool for developing nerve-stimulating electrodes.
\end{abstract}

Keywords: electrical impedance, electrical impedance spectroscopy, bio-impedance, voltage response, current source, platinum, rat sciatic nerve, electrode-nerve tissue interface

Izdelali in preizkusili smo napravo za štiri-točkovno merjenje električne impedance $(Z)$ perifernih živcev, katere osnova je odprtokodna merilna in kontrolna konzola (Red Pitaya). Naprava je bila preizkušana na izoliranem živcu ischiadicus pri podgani (RSN) tako, da smo živec lahko dražili z izbranimi tokovnimi stimulacijskimi impulzi. Preverili smo hipotezo, da izbrani stimulacijski impulzi izzovejo razlike na dvojni plasti (DL) prehoda med platinovo (Pt) stimulacijsko elektrodo in živčnim tkivom. Z metodo impedančne spektroskopije smo izmerili $Z$ na prehodu med Pt elektrodo in živčnim tkivom. Analiza frekvenčnega odgovora RSN, medtem ko je bil stimuliran s posebnimi tokovnimi stimulacijskimi impulzi, je podala od sestave in zgradbe odvisne električne lastnosti živca. Nadalje je analiza sočasno merjenega napetostnega odgovora (VR) pokazala, da nobena od obeh, tako največja negativna polarizacija $E_{\mathrm{mc}}$ kot tudi največja pozitivna polarizacija $E_{\mathrm{ma}}$, na prehodu med elektrodo in elektrolitom, ni presegla varne meje pri kateri lahko pride do elektrolize vode. Zaključujemo, da napetostne in tokovne razlike, ki so nastale na DL prehodu med Pt stimulacijsko elektrodo in živčnim tkivom, nimajo škodljivega učinka na živčno tkivo. Končni sklep raziskave je, da je mogoče pridobljene elektrofiziološke rezultate koristno uporabiti pri nadaljnem načrtovanju in razvoju stimulacijskih elektrod.

Ključne besede: električna impedanca, električna impedančna spektroskopija, bioimpedanca, napetostni odgovor, tokovni vir, platina, kolčni živec podgane, prehod med elektrodo in živčnim tkivom

\section{INTRODUCTION}

Tissue-characterizing techniques based on electrical impedance $(Z)$ are being used to study the $Z$ variations of biological tissues over a range of frequencies. Some of these analysing techniques provide $Z$ values of the tissue sample as a lumped estimation at a suitable frequency range and the information on several complex bioelectrical phenomena occurring in cells and tissues under an alternating (AC) electric current signal. ${ }^{1,2}$ In this regard, a measurement of the complex $Z$ in biological systems is one of the developing technologies for monitoring and determining the pathological and physiological status of biological tissues. ${ }^{3}$ Namely, with AC electrical stimulation, biological tissues produce a complex $Z$ that depends on the tissue composition, structures, health status, and applied stimulus frequency. ${ }^{4}$

In biological tissues, plasma membranes of the cells are composed of electrically non-conducting lipid bilayers and an ion-conducting proteins channels. ${ }^{5,6}$ This structure provides a capacitance to the applied AC signal and contributes to the overall response of the biological tissues by producing a complex $Z$, which is a function of the tissue composition as well as the frequency of the applied AC signal. $Z$ is a measurement of the overall 
ability of a medium to conduct electrical current, defined as the ratio of the voltage in an object to the current in a conductive medium. $Z$ is a complex quantity, which consists of a real part (resistance) and an imaginary part (reactance). ${ }^{7}$ Its units are ohms $(\Omega)$. In this regard, Wtorek et al. ${ }^{8}$ presented the construction of a probe for immittance spectroscopy based on the four-electrode technique. They tested the probe in "in-vivo" measurements on swine gluteal tissue.

The simplest set-up for measuring $Z$ is the so-called two-probe set-up, where a current source is used in order to feed a known current $(I)$ into the unknown $Z$. A voltage measurement using a voltage-measurement device determines the voltage drop, which is assumed to be proportional to the unknown $Z$. However, the resistivity of cables and the contact resistance also fully contribute to the voltage drop and to the measured voltage. As a result, the measurement result $Z$ is actually higher than the true $Z$.

In the diagnosis of neuromuscular diseases, for instance, the $Z$ of muscles can be measured to monitor patients with amyotrophic lateral sclerosis, muscular dystrophy and inflammatory myopathies. In clinical practice, a surface-electrode $Z$ measurement is used for $Z$ measurements of the skin tissue, which can be used for monitoring various conditions relating to the physical or medical state of a patient. The accuracy of a $Z$ measurement with surface electrodes can be degraded by unknown contact impedances.

In order to avoid the disadvantages of the two-probe, $Z$ measurement set-up, the four-probe, $Z$ measurement set-up employs an additional pair of electrodes. In the four-probe, $Z$ measurement set-up, the current is fed through two feeding electrodes ${ }^{1,4}$ (considered as drive terminals) within the line of four equidistantly placed electrodes, while the voltage drop is measured between two measurement electrodes ${ }^{2,3}$ (considered as measurement terminals). The voltage is measured with an instrument that has a very high input $Z$, so that almost no current flows through the measurement electrodes, i.e., their cables and contact resistance play almost no role in the measurement. Therefore, the measured voltage is almost identical to the voltage drop at the unknown $Z .{ }^{9}$ For many applications, the four-probe, $Z$ measurement set-up thus provides sufficient accuracy.

The measurement of $Z$ in biological systems, such as nerve tissue, with the four-probe measurement set-up, eliminates the influence of the $Z$ of the electrode/nerve tissue interface on the nerve tissue $Z$. Namely, electrode polarization is avoided and the contact $Z$ is eliminated from the measurement. ${ }^{10,11}$ However, the $Z$ measurement error cannot be fully eliminated due to current flow through the measurement electrodes. As the use of $\mathrm{Pt}$ electrodes in selective nerve-stimulation applications (SNS) became indispensable, significant research was dedicated to understanding the electrode-electrolyte interface in "in vivo" and the electrode-nerve tissue interface in "in vivo". Of particular importance to SNS is Schwan's limit of linearity: the voltage at which the electrode system's $Z$ becomes nonlinear and is often exceeded during SNS. ${ }^{12,13}$

The main goal of this study was to use the electrical impedance spectroscopy (EIS) and voltage response (VR) experimental results to enhance our understanding of the effect of physical processes at the interface $Z$, with the expressed purpose of improving the interface design of future multi-electrode stimulating systems for SNS. The measurements were performed to test the hypothesis that a specific waveform of current stimulating pulse elicits controlled and tissue-safe voltage differences at the double layer (DL) of the interface between the Pt stimulating electrode and the nerve tissue. These repetitive voltage differences are potentially harmful since over time they can prevent effective excitation of the nerve tissue at the stimulating electrode due to electrolysis-induced nerve-tissue damage.

\section{MATERIAL AND METHODS}

\subsection{Experimental design and set-up}

Among the several custom-designed pieces of equipment, the most important was a temperature-controlled measuring chamber and proprietary stimulation/recording cables (Figure 1d). The chamber was developed for the two-probe and the four-probe electrophysiological measurements. The bulk body of the chamber was machined out of Plexiglas, using a computerized numerical control milling machine. The main part of the chamber was a ladder with seven Pt hook-shape electrodes mounted horizontally over the chamber aperture and filled with a Krebs-Ringer solution (154-mM NaCl, 5-mM KCl, 2-mM $\mathrm{CaCl}_{2}, 1-\mathrm{mM} \mathrm{MgCl}_{2}, 5-\mathrm{mM}$ HEPES, 11-mM D-glucose, $\mathrm{pH}$ 7.4). The distance between the electrodes was $4.8 \mathrm{~mm}$.

The hook-shape electrodes were manufactured from a cold-drawn Pt wire (99.99 \% purity) with a thickness of $1 \mathrm{~mm}$. Pure Pt is commonly used as a stimulating electrode material because it can effectively supply highdensity electrical charge to activate the neural tissue. Pt is normally used in the form of a pure metal because impurities and alloying elements may adversely affect its mechanical characteristics, working characteristics and its stability against corrosion in physiological media. Pt also has many physical properties that are of great value for their use in the technology of implantable stimulating electrodes. The contact surface of the Pt electrodes was increased, relative to the electrodes' geometric area, by sanding with a metallurgical grade sandpaper number 1000 .

Consequently, in the developed measuring system, the two Pt hooks (electrode 1 and 7 ) of the ladder, representing the first two points of the four-probe measuring set-up, are used as shown in Figure 1d. For measurements of the voltage drop elicited by the current 


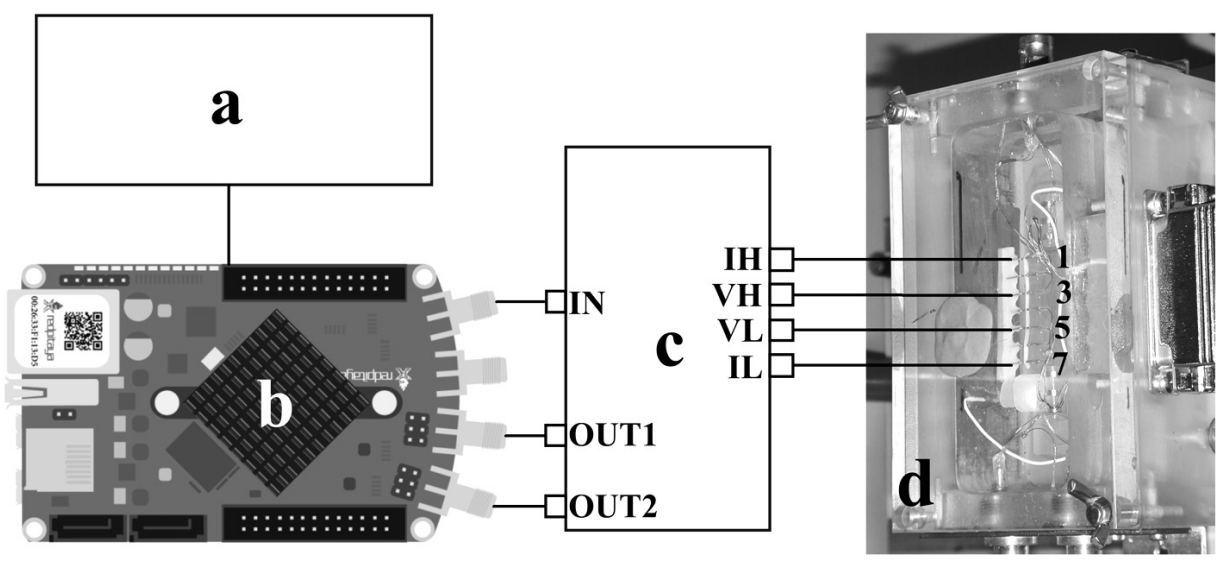

Figure 1: Schematic diagram of the stimulating/measuring set-up: a) programming part of the $Z$ measurement set-up, b) Red Pitaya, c) $Z$ front-end device, d) 3D view of the measuring chamber with a ladder of electrodes

Slika 1: Shematski prikaz stimulacijsko/merilne naprave: a) programska enota naprave za merjenje $Z$, b) Red Pitaya, c) vhodno izhodna naprava $(Z)$, d) tridimenzionalna slika merilne celice $\mathrm{z}$ lestvico elektrod

pulse, the two hooks (electrode 3 and 5) representing the second two probes of the four-probe measuring set-up, were used. The hook electrode 1 is connected to the high current source output $\left(I_{\mathrm{H}}\right)$ of the bio-impedance front-end device (Figure 1c), while the hook electrode 7 is connected to the low current source output $\left(I_{\mathrm{L}}\right)$ of the bio-impedance front-end device. Electrode 3 was connected to the high-voltage input $\left(V_{\mathrm{H}}\right)$ of the bio impedance front-end device and electrode 5 was connected to the low-voltage input $\left(V_{\mathrm{L}}\right)$ of the bio impedance front-end device. Before the rat's sciatic nerve (RSN) was placed on the ladder of electrodes, the chamber canal was filled with saline to prevent the drying out of the RSN. To reduce the polarization and voltage shifts, the electrodes were soaked for $15 \mathrm{~min}$ to $30 \mathrm{~min}$.

\subsection{Nerve dissection and preparation}

$Z$ measurements were performed on two isolated RSNs harvested from adult male Wistar rats, weighing $300 \mathrm{~g}$ to $350 \mathrm{~g}$, purchased from Charles River. Animal handling complied with the Prevention of Cruelty to Animals law, which is consistent with the European Community Directive 2010/63/EU and was approved by the Institutional Review Board. The rats are euthanized by $\mathrm{CO}_{2}$ and exsanguination. Dissection began with an incision through the skin on the lateral side of the hind limb from the knee to the hip region. To expose the RSN, the superficial layer of the thigh muscle is carefully dissected between the $\mathrm{m}$. gluteus superficialis and $\mathrm{m}$. biceps femoris. The length of RSN available for measurement depends on the point at which the RSN divides into the peroneal, tibial and sural nerves. To prevent nerve injury during handling, a thread was tied around the distal end of the RSN. After the attached tissue was removed from the RSN, the RSN was cut as close to the knee joint as possible. Similarly, at the proximal end, the RSN was cut as close as possible to the spinal column. By doing so, the RSN obtained was long enough (between $30 \mathrm{~mm}$ and $35 \mathrm{~mm}$ ) to be in contact with all the electrodes in the ladder.

Afterwards, the RSN was placed in a glass silicon-lined Petri dish filled with Krebs-Ringer solution. As the buffer was used for cell physiology experiments, it was gassed with $100 \%$ oxygen for 10-20 min, so that the RSN could recover from the dissection. The RSN was transferred from the Petri dish into the chamber and placed on the ladder so that it touched all the electrodes. The RSN was kept moist with saline to prevent it from drying out and rendering it useless for the experiment. Finally, to prevent evaporation and drying of the tissue the chamber was covered with a lid. All of the recordings were made at an ambient temperature of $22-23{ }^{\circ} \mathrm{C}$.

\subsection{Measuring system}

The Red Pitaya (Red Pitaya, Solkan, Slovenia) development platform was used for the stimulating/measuring set-up shown schematically in Figure 1. This platform enables signal generation, signal acquisition and signal processing.

The set-up used two built in D/A and A/D converter inputs enabling measurements with a 14-bit resolution at a $125 \mathrm{MHz} / \mathrm{s}$ sampling rate. This sampling rate could be adjusted with a decimal/dividing factor to $1,8,64,1024$, 8192 and 65536, respectively. Red Pitaya was attached to the $Z$ front-end device as shown in Figure 1c. This device was composed of a voltage-controlled current source (VCCS) based on the Howland method. The VCCS was designed to provide a constant current signal $\left(i_{\mathrm{c}}\right)$, up to $4 \mathrm{~mA}$, independent of the value of the attached load within a frequency range from $1 \mathrm{~Hz}$ to $1 \mathrm{MHz}$. The $Z$ front-end device enabled simultaneous, four- and two-probe $Z$ measurements.,

\subsection{Bio-impedance spectroscopy measurements}

The EIS-based frequency response studies of $Z$, of any material, can provide the material's structure- and 
composition-dependent electrical properties as well as its frequency response. ${ }^{14}$ In this study, EIS was used to estimate the complex $(Z(f))$ and phase angle $(\theta(f))$ of the RSN at different frequencies $f_{\mathrm{i}}\left(f_{\mathrm{i}}: f_{1}, f_{2}, f_{3}, \ldots, f_{\mathrm{n}}\right)$ by measuring the surface voltage $(V(f))$ developed for a constant low-amplitude, low-frequency alternating sinusoidal current $(I(f))$ injected into a RSN using both the two- and four-probe methods. ${ }^{15-18}$ Afterwards, the frequency-dependent electrical bio-impedance $Z\left(f_{\mathrm{i}}\right)$ was found as the transfer function of the RSN, and thus the $Z\left(f_{\mathrm{i}}\right)$ was calculated by dividing the voltage data $\left(V\left(f_{i}\right)\right)$ measurement by the applied current $\left(I\left(f_{\mathrm{i}}\right)\right)$, as shown in the following Equation (1):

$$
Z\left(f_{\mathrm{i}}\right)=V\left(f_{\mathrm{i}}\right) / I\left(f_{\mathrm{i}}\right)
$$

The programming part of the $Z$ measurement set-up, shown in Figure 1a, was performed with a Lenovo T420 portable computer (Lenovo, Singapore) and MATLAB R2007a software (The Mathworks Inc., USA). In this way, communication and concomitant functional control of the Red Pitaya was made and monophasic and biphasic voltage pulses to drive (driving pulse) a VCCS within the front-end device, having a specific waveform shown in Figures $\mathbf{2 a}$ and $\mathbf{2 b}$, were generated. An aforementioned waveform of the stimulating pulse was adopted from a recent study where this waveform was tested by selective nerve stimulation of the isolated porcine left cervical vagus nerve segment. ${ }^{19}$ Afterwards, driving pulses were delivered to the VCCS, where they were converted into constant current pulses by means of
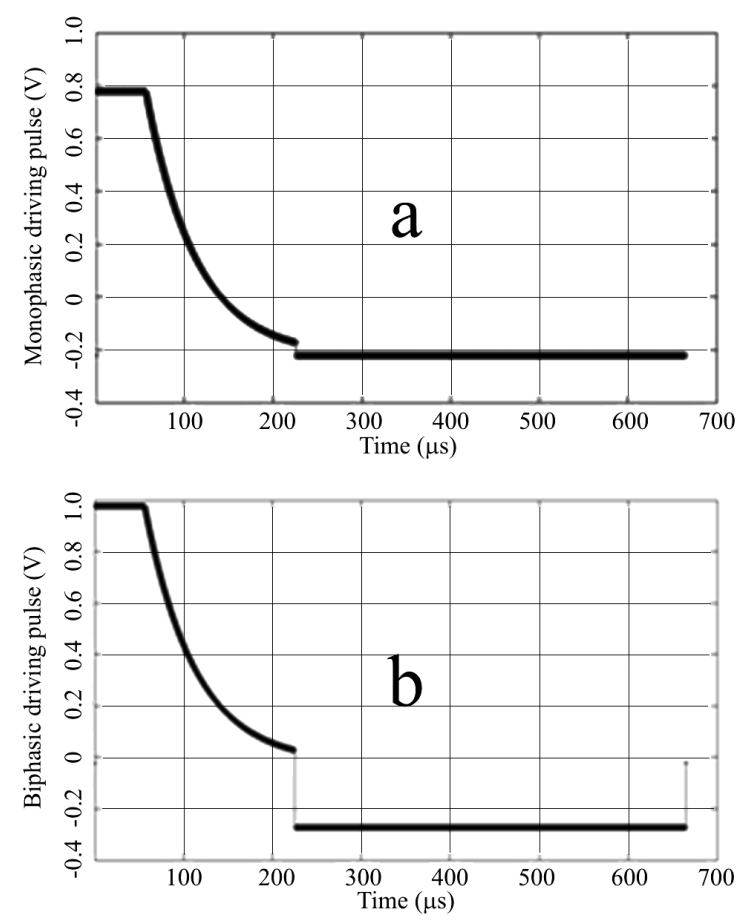

Figure 2: Voltage driving pulses to control the VCCS current source: a) a monophasic pulse and b) a biphasic pulse

Slika 2: Napetostna krmilna pulza za kontrolo VCCS tokovnega vira: a) monopolarni pulz in b) bipolarni pulz the high-output-impedance current generator. To avoid a measurement error in developing the presented $Z$ measurement set-up, it was essential that a high-output $Z$ was maintained over the operating frequency range so that the injected current was constant and that the current source did not load the sample. ${ }^{20}$ The stimulating current pulses, having precisely the same waveform as the driving pulses that were delivered to the VCCS, were constant current, biphasic, partially charge-balanced and asymmetric, composed of a precisely determined quasi-trapezoidal cathodic phase with a square leading edge of intensity $i_{\mathrm{c}}$, a plateau of the cathodic phase with the width of $t_{\mathrm{c}}$, followed by an exponentially decaying phase with the width of $t_{\exp }$ and the time constant $\hat{\boldsymbol{o}}_{\exp }$, and ended by a wide, rectangular, anodic phase with the width $t_{\mathrm{a}}$ and intensity of $i_{\mathrm{a}}$.

In the four-probe measurement, the generated current stimulating pulse waveform $i_{\mathrm{c}}$ was applied to an isolated RSN via the two outer hook electrodes within the ladder, electrode number 1 and electrode number 7 that served as current feeding probes $I_{\mathrm{H}}$ and $I_{\mathrm{L}}$. They were separated from the electrodes number 3 and 5 that served as voltage probes $V_{\mathrm{H}}$ and $V_{\mathrm{L}}$, respectively. In the two-probe measurement, the generated current stimulating pulse was applied on an isolated RSN via the electrode number 1 , serving as a current feeding probe $I_{\mathrm{H}}$, and connected to the electrode number 3 that served as a voltage probe $V_{\mathrm{H}}$ and via the electrode number 7 , that served as a current feeding probe $I_{\mathrm{L}}$ and was connected to electrode number 5 that served as a voltage probe $V_{\mathrm{L}}$.

These measurements were used to obtain the Bode and Nyquist diagrams with which the equivalent circuit model elements could be calculated for each of the samples. The Nyquist diagram consists of a Zimaginary vs. Zreal plot, representing the imaginary and real values for the $Z$. This paper however, only reports an "in-vitro" study of RSN samples conducted using EIS to find the frequency-dependent $Z$.

\subsection{Voltage-response (VR) measurements}

The presented set-up also enabled measurements of $V R$ s that were elicited in the RSN using generated quasi-trapezoidal monophasic and biphasic pulses. The generated stimulating pulse was measured indirectly as a voltage drop at the reference resistor with a trains impedance amplifier to assess the value of the phase angle $\theta$. Later on, this value was used in the processing of data for the $Z$ calculation. The aforementioned stimulating pulse was used for excitation of the RSN that represented a floating load; therefore, the elicited voltage drop was measured differentially using an instrumental amplifier.

The RSN was stimulated with the generated current pulses while information on the $V R$ and stimulating current was recorded simultaneously. In this regard, $i_{c}$ was $1.8 \mathrm{~mA}$ while $t_{\mathrm{c}}$ was $60 \mu \mathrm{s}$. In each measurement, where 50 pulses were generated, the last pulse was saved and a time to gap of $250 \mu$ s was introduced. The EIS was per- 
formed using current sinusoidal signals with an amplitude of $400 \mu \mathrm{A}$ that were generated at frequencies evenly distributed within the frequency range between $1 \mathrm{~Hz}$ and $500 \mathrm{kHz}$ and delivered to the RSN. While the RSN was stimulated with the aforementioned current sinusoidal signals, the stimulating current and $V R$ were saved again. All of the data were analysed off-line and $Z$ was calculated with the lock-in method.

\section{RESULTS}

\subsection{Bio-impedance spectroscopy}

Figure 3a shows the Bode diagram of the absolute value of $Z$, measured on the RSN, using the two- and four-probe set-ups while the RSN is stimulated with two specific monophasic and biphasic excitation pulses, respectively. Figure $\mathbf{3 b}$ shows the $\theta$ obtained with the twoand four-probe set-ups expressed in the Bode diagram during RSN stimulation with monophasic and biphasic stimuli. Figure 3c shows the $Z$ spectrum measured with the two- and four-probe set-ups, presented with the Nyquist diagram (Cole-Cole diagram), while the RSN is stimulated with monophasic and biphasic stimuli.

The absolute $Z$ value, expressed in the Bode diagram while the RSN is stimulated with monophasic and biphasic stimuli and measured using the two-probe set-up, decreased almost exponentially from approximately $60 \mathrm{k} \Omega$ measured at $1 \mathrm{~Hz}$ to slightly below $800 \Omega$ measured at $20 \mathrm{kHz}$ (Figure 3a). At frequencies between $20 \mathrm{kHz}$ and $100 \mathrm{kHz}, Z$ remained almost unchanged; at frequencies above $100 \mathrm{kHz}$, however, $Z$ began to decrease rapidly. It was noted that traces of $Z$ belonging to stimulation with monophasic and biphasic stimuli were almost identical.

Figure 3b, representing the $\theta$ expressed in the Bode diagram, shows that for the two-probe measurement, the capacitive nature of an interface between RSN and platinum electrodes prevailed at frequencies below $500 \mathrm{~Hz}$. Namely, a corresponding $\theta$ measured at $1 \mathrm{~Hz}$ was $-60{ }^{\circ} \mathrm{C}$ and $\theta$ measured at $500 \mathrm{~Hz}$ was $-10{ }^{\circ} \mathrm{C}$, respectively. At frequencies between $500 \mathrm{~Hz}$ and $30 \mathrm{kHz}$, the nature of the interface remained still slightly capacitive, expressing the same value of the phase angle $\theta$, i.e., $-10{ }^{\circ} \mathrm{C}$. Within this frequency range, the ohmic nature of the interface between the RSN and platinum electrodes prevailed. At frequencies above $100 \mathrm{kHz}$, however, the nature of the interface between the RSN and the platinum electrodes started to be progressively capacitive again, expressing the sharp decrease of $\theta$ towards negative values. The traces of $\theta$, belonging to the stimulation with the monophasic and biphasic stimuli, were almost identical.

In Figure 3c, the $Z$ spectra measured with two- and four-probe set-ups expressed in a Nyquist diagram (Cole-Cole diagram) while the RSN is stimulated with monophasic and biphasic stimuli differ considerably. This diagram represents the relationship between the imaginary and the real component of $Z$, as measured at the interface between the RSN and the particular platinum electrodes using the two- versus four-probe set-up and monophasic versus biphasic stimuli. In other words, this diagram represents the relationship between capacitive and ohmic natures of the interface between the RSN and the platinum electrodes. The difference was not significant for monophasic versus biphasic stimuli but was for the two- versus four-probe measurements. Traces of $Z$ spectra, belonging to stimulation with monophasic and biphasic stimuli, were almost identical for the two- as well as for the four-probe measurements. For the two-
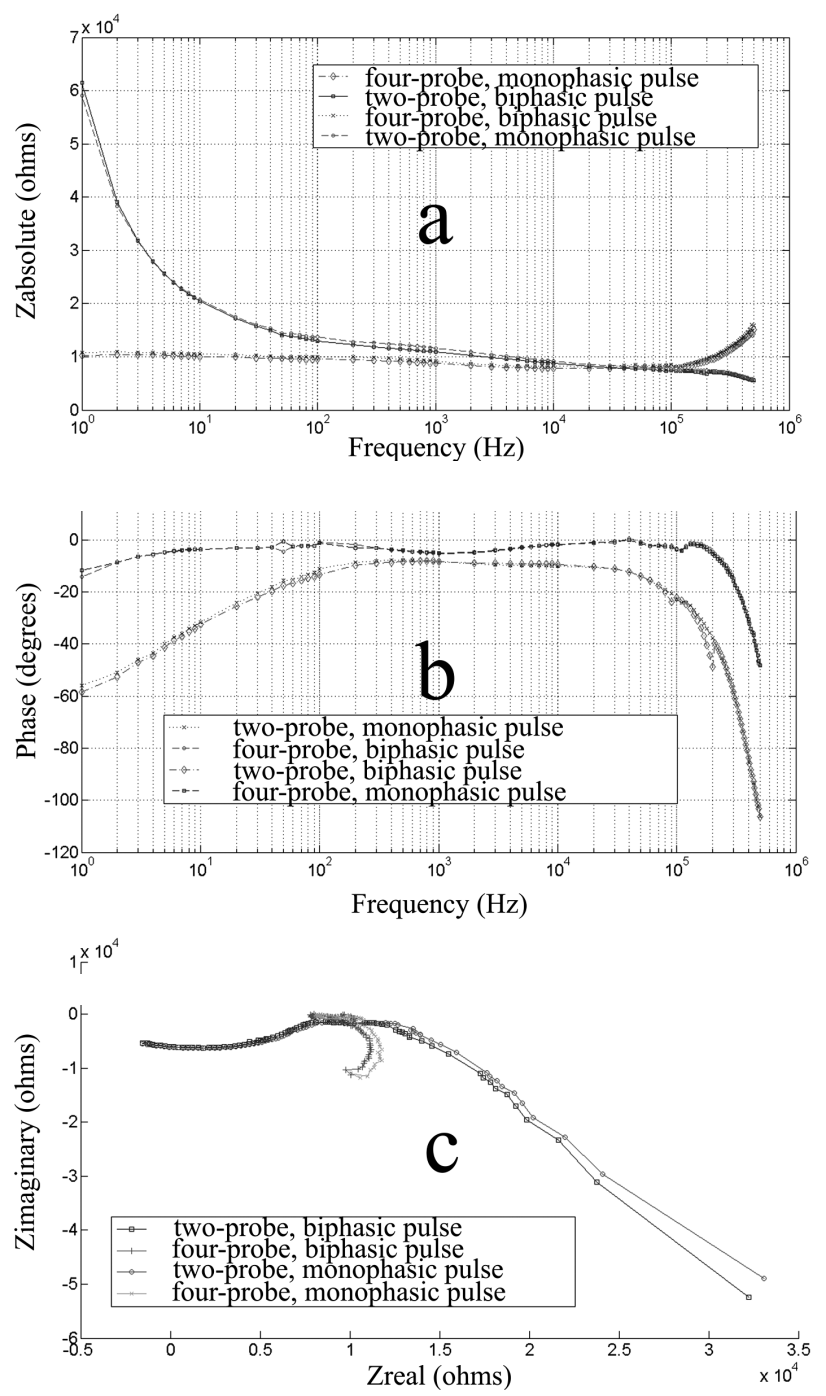

Figure 3: Results of $Z$ spectroscopy measurements while the RSN is stimulated with monophasic and biphasic stimuli: a) Absolute $Z$ value measured with a two- and four-probe set-ups expressed in a Bode diagram, b) $\theta$ obtained with a two- and four-probe set-ups expressed in a Bode diagram, c) $Z$ spectrum measured with two- and four-probe set-ups expressed in a Nyquist diagram (Cole-Cole diagram)

Slika 3: Rezultati spektroskopskih meritev $Z$, medtem, ko je bil RSN stimuliran $\mathrm{z}$ monofaznimi in bifaznimi pulzi: a) absolutna vrednost $Z$ merjena $\mathrm{z}$ dvo in štiritočkovno metodo, prikazana $\mathrm{z}$ Bodejevim diagramom, b) $\theta$ merjen $\mathrm{z}$ dvo in štiritočkovno metodo, prikazan $\mathrm{z}$ Bodejevim diagramom, c) spekter $Z$ merjen $z$ dvo in štiritočkovno metodo prikazana z Nyquistovim diagramom (Cole-Cole diagram) 
and four-probe measurement, the $Z$ spectrum below 10 $\mathrm{k} \Omega$ of the real/ohmic component, showed an almost identical relationship between the imaginary/capacitive and the real/ohmic nature of the interface between the RSN and the Pt electrodes. Above $10 \mathrm{k} \Omega$ of real/ohmic component, however, the two-probe measurement showed an almost linear decrease of an imaginary/capacitive nature and, at the same time, an almost linear increase of the real/ohmic nature, while the four-probe measurement showed no further increase in the real/ohmic nature.

\subsection{Voltage-response (VR) measurements}

$V R$ s, during the excitation of the RSN with the quasi-trapezoidal monophasic and biphasic pulses using
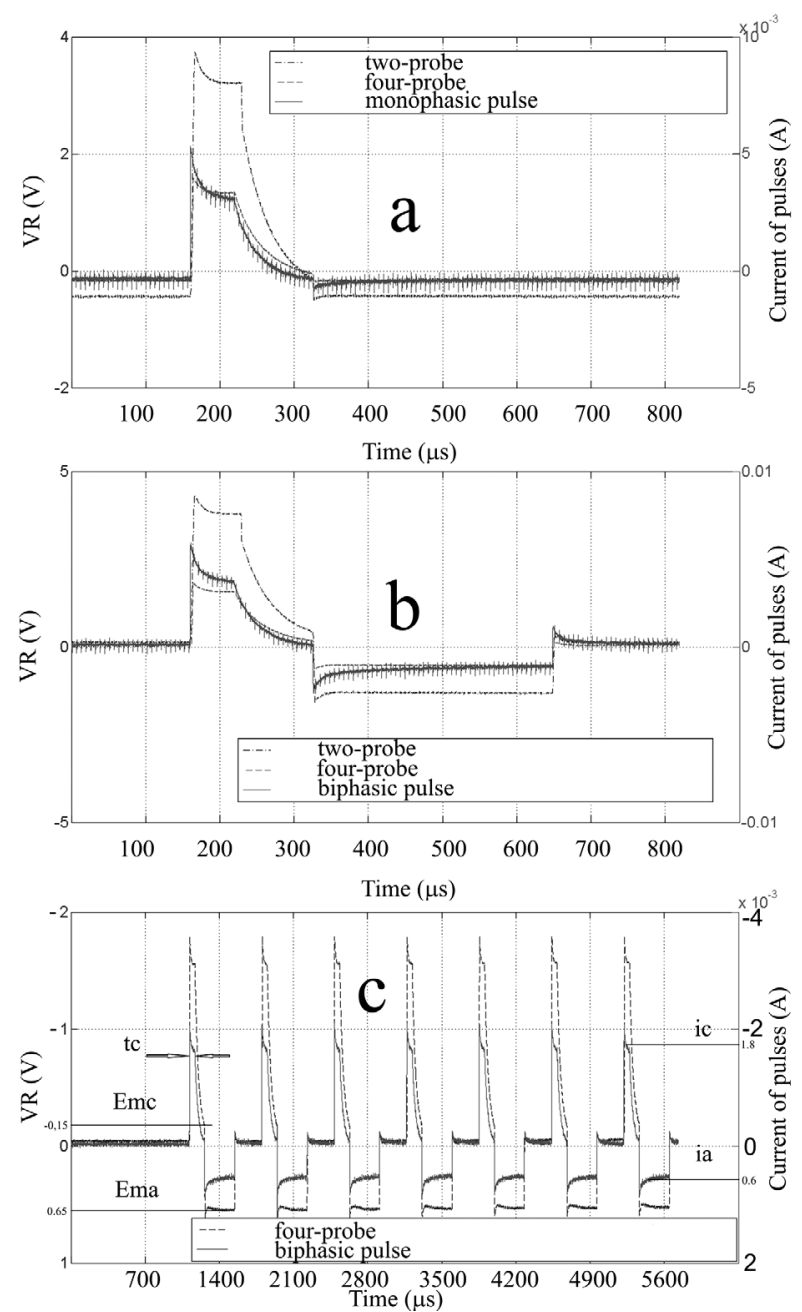

Figure 4: Stimulation pulses and corresponding $V R \mathrm{~s}:$ a) $V R \mathrm{~s}$ measured using a two- and four-point measurements elicited with a monophasic pulse, b) VRs measured using a two- and four-point measurements elicited with a biphasic pulse, c) $V R$ s measured using a four-point measurement elicited with a train of biphasic pulses

Slika 4: Stimulacijski pulzi in pripadajoči $V R$-ji: a) $V R$-ji merjeni z dvo in štiritočkovno metodo, izzvani z monofaznim pulzom, b) $V R$-ji merjeni $\mathrm{z}$ dvo in štiritočkovno metodo, izzvani z bifaznim pulzom, $\mathrm{c}$ ) $V R$-ji merjeni $\mathrm{z}$ dvo- in štiritočkovno metodo, izzvani $\mathrm{z}$ vlakom bifaznih pulzov the two- and four-point measurement set-ups, are shown in the Figures $\mathbf{4 a}$ to $\mathbf{4 c}$. Figure $\mathbf{4 a}$ shows the VRs elicited with a monophasic pulse and measured with the two- and four-point set-ups. VRs measured with the four-point set-up follow the quasi-trapezoidal pulse more accurately than the VRs measured using the two-point set-up. This was in accordance with Figure 3 where the real/ohmic nature of the interface between the RSN and the Pt electrode in the four-point measurement prevails over the imaginary/capacitive nature of the interface between the RSN and the Pt electrode.

Figure 4b shows VRs measured with the two- and four-point set-ups elicited with the biphasic pulse. VRs measured with the two-point set-up follow the quasi-trapezoidal pulse more accurately than the VRs measured with the four-point set-up. This is in accordance with Figure 3 where the real/ohmic nature of the interface between the RSN and the Pt electrode in the four-point measurement prevails over the imaginary/capacitive nature of the interface between the RSN and the Pt electrode.

As seen in all three panels of Figure 3, the leading edge of the cathodic phase $i_{\mathrm{c}}$ and the plateau of the cathodic phase with the width $t_{\mathrm{c}}$ of the generated stimulating current pulses were not of exactly the same shape as the waveform of pulses that were delivered to the VCCS. Other parts of the generated current pulses, such as exponentially decaying phase with the width of $t_{\exp }$ and the time constant $\tau_{\exp }$ in both monophasic and biphasic pulses as well as the rectangular, anodic phase with the width $t_{\mathrm{a}}$ and intensity of $i_{\mathrm{a}}$ in the biphasic pulse, are almost identical. It was presumed that in calculations of $Z$, after a monophasic and biphasic pulse, the aforementioned dissimilarity did not influence $Z$ significantly.

Figure 4c shows $V R$ s measured using the four-point set-up, elicited with a train of generated biphasic pulses with a cathodic intensity $\left(i_{\mathrm{c}}\right)$ of $1.8 \mathrm{~mA}$ and the elicited $V R \mathrm{~s}$ with the entire voltage drop of $\Delta \mathrm{V}=1.7 \mathrm{~V}$. As shown in Figure $\mathbf{4 c}$, an onset of $i_{\mathrm{c}}$ elicited the near-instantaneous voltage increase with the same time course. However, when $i_{\mathrm{c}}$ was terminated, the course of the voltage in the exponential decay region where $i_{\mathrm{c}}$ exponentially approached the lowest value, the voltage also exponentially approached the value of approximately $-0.15 \mathrm{~V}$. Almost at the same time as the cathodic pulse $i_{\mathrm{c}}$ was terminated, the onset of an anodic intensity $\left(i_{\mathrm{a}}\right)$ of $0.6 \mathrm{~mA}$ elicited the near-instantaneous positive voltage of approximately $0.65 \mathrm{~V}$, having a slightly different course.

As in the VR of the tested stimulation pulse, the maximum negative polarization across the electrode-nerve tissue interface $\left(E_{\mathrm{mc}}\right)$ and the maximum positive polarization across the electrode-nerve tissue interface $\left(E_{\mathrm{ma}}\right)$ reached $-0.15 \mathrm{~V}$ and $0.65 \mathrm{~V}$, respectively. None of them exceed the safety limit range for water electrolysis, from $-0.60 \mathrm{~V}$ to $+0.85 \mathrm{~V}^{21}$ 


\section{DISCUSSION}

The presented work demonstrates the feasibility of a $Z$ measurement on an isolated RSN with quasi-trapezoidal current biphasic stimulating pulses. The feasibility of the stimulating paradigm, where the specific stimulus waveform was used to selectively stimulate different types of nerve fibres within the cervical segment of porcine vagus nerve, has already been published. ${ }^{19}$

In the last two decades, particular attention has been paid to vagus nerve stimulation techniques that are used to treat, among others, a number of nervous-system disorders, neuropsychiatric disorders, eating disorders, sleep disorders, cardiac disorders, endocrine disorders, and pain. ${ }^{22-25}$ Considerable scientific and technological efforts have been devoted to developing systems of electrodes that interface the human vagus nerve with electronic implantable devices. ${ }^{26,27}$

The $Z$ characterization of the electrode-electrolyte interface is of paramount importance in the field of neuroprotheses, where small electrodes are required for SNS and recording of superficial regions of peripheral nerves via multi-electrode systems. The electrode-electrolyte interface is determined from the known electrode $\mathrm{Z}$, which should be as low as possible to avoid nerve tissue damage. A high $Z$ would result in a large applied electrode voltage leading to undesirable electrochemical reactions that damage the nerve tissue. ${ }^{28}$ As shown in the presented study, neither the maximum negative polarization across the electrode-electrolyte interface $\left(E_{\mathrm{mc}}\right)$, nor the maximum positive polarization across the electrode-electrolyte interface $\left(E_{\mathrm{ma}}\right)$, exceeded the safety limits for water electrolysis. ${ }^{21}$

Nevertheless, large surface area stimulating electrodes (due to a roughened surface), with a relatively much smaller geometric surface area and thus a much lower $\mathrm{Z}$ than current designs, could be beneficial, especially where a larger number of stimulating electrodes within the multi-electrode system ${ }^{29}$ is needed. The authors demonstrated "in vitro" that by increasing the real surface area of stimulating electrodes, a significantly lower polarization impedance and electrode impedance, as well as a low residual direct current, could be obtained. Also, all three electrical parameters, electrode impedance, access resistance and polarization, could be calculated from the current and voltage measurements. Thus, a theoretical equivalent circuit model of the interface between the RSN and Pt electrodes could be modelled by fitting the equivalent circuit model elements to the EIS-based frequency-response spectroscopy experimental results. ${ }^{28,30,31}$

\section{CONCLUSIONS}

The first conclusion is that at frequency range between $0 \mathrm{kHz}$ and $2.5 \mathrm{kHz}$, which confines the power spectrum density of the proposed quasi-trapezoidal stimulating pulse (power spectrum density not shown in this paper), the ohmic nature of the interface between RSN and Pt electrodes prevailed over the imaginary/ capacitive nature, yielding the relative low $Z$ of approximately $1 \mathrm{k} \Omega$.

The second conclusion is that the differences elicited at the DL of the interface between the Pt stimulating electrode and the nerve tissue, while the RSN was stimulated using biphasic quasi-trapezoidal stimuli, have not exceeded the voltage range considered safe for nerve tissue.

The third conclusion is that the designed and tested four-probe bio-impedance measurement set-up, based on the Red Pitaya open-source measurement and control tool, provided data on the structure- and composition-related electrical properties of the RSN tissue that contribute to the development of multi-electrode nerve stimulating systems.

\section{Definitions of field-specific terms}

SNS - selective nerve stimulation

$\mathrm{RSN}$ - segment of a rat sciatic nerve

$\mathrm{AC}$ - alternating current

$Z$ - electrical impedance

VCCS - voltage controlled current source

driving pulse - voltage pulses to drive a VCCS

EIS - Electrical impedance spectroscopy

$\mathrm{Pt}-$ platinum

chamber - temperature-controlled measuring chamber

$\mathrm{CNC}$ - computerized numerical control

$i_{\mathrm{c}}-$ intensity of the cathodic phase

$t_{\mathrm{c}}$ - width of the cathodic phase

$t_{e x} \mathrm{p}$ - width of the cathodic exponential decay

$\tau_{\text {exp }}$ - time constant of the exponential decay

$i_{\mathrm{a}}$ - intensity of the anodic phase

$t_{\mathrm{a}}$ - width of the anodic phase

$I_{\mathrm{H}}$ and $\mathrm{IL}$ - current feeding probes

$V_{\mathrm{H}}$ and $\mathrm{VL}$ - voltage probes

$V R$ - voltage response

$R$ - reference resistor

$\theta$ - phase angle

DL - double layer

$E_{\mathrm{ma}}-$ maximum positive polarization across the electrode-electrolyte interface

$E_{\mathrm{mc}}$ - maximum negative polarization across the electrode-electrolyte interface

\section{Acknowledgement}

This work was financed by the research grant P3-0171 and P4-0053 from the Slovenian Research Agency (ARRS), Ministry of Education, Science and Sport, Ljubljana, Republic of Slovenia. The authors acknowledge Professor Dejan Križaj from the Faculty of Electrical Engineering, University of Ljubljana, for the 
useful discussion and enabling us to use a measuring set up developed in his laboratory.

\section{Ethical approval}

The neural tissue was treated in accordance with the approval guidelines of the ethics committee of the Veterinary Administration, Ministry of Agriculture, Forestry and Food, Republic of Slovenia.

\section{Conflict of interest statement}

The authors declare that there are no conflicts of interest regarding the publication of this paper. None of the authors received any financial or other compensation for undertaking this study or during its execution. No personal relationships with other people or organizations inappropriately influenced the work.

\section{REFERENCES}

${ }^{1}$ T. K. Bera, J. Nagaraju, Electrical impedance spectroscopic study of broiler chicken tissues suitable for the development of practical phantoms in multifrequency EIT, J Electr Bioimp, 2 (2011), 48-63, doi:10.5617/jeb. 174

${ }^{2}$ H. P. Schwan, Electrical properties of tissue and cell suspensions, Adv Biol Med Phy, 5 (1957), 147-209

${ }^{3}$ H. Solmaz, Y. Ülgen, M. Tümer, Design of a Cole-Cole Meter for Complex Impedance Measurement of Living Tissues, Biomedical Engineering, 7 (2010), doi:10.2316/Journal.216.2010.7.680-137

${ }^{4}$ J. J. Ackmann, Complex bioelectric impedance measurement system for the frequency range from $5 \mathrm{~Hz}$ to $1 \mathrm{MHz}$, Ann Biomed Eng, 21 (1993) 2, 135-146

${ }^{5}$ R. W. Griffiths, M. E. Philpot, B. J. Chapman, K. A. Munday, Impedance cardiography: non-invasive cardiac output measurement after burn injury, Int J Tissue React, 3 (1981) 1, 47-55

${ }^{6}$ C. J. Schuster, H. P. Schuster, Application of impedance cardiography in critical care medicine, Resuscitation, 11 (1984) 3-4, 255-274

H. Solmaz, Y. Ülgen, M. Tümer, Design of a microcontroller based Cole-Cole impedance meter for testing biological tissues, World Congress on Medical Physics and Biomedical Engineering, 2009, doi:10.1007/978-3-642-03885-3_135

${ }^{8}$ J. Wtorek, A. Bujnowski, A. Poliński, L. Józefiak, B. Truyen, A probe for immittance spectroscopy based on the parallel electrode technique, Physiol Meas, 25 (2004) 5, 1249-1260, doi:10.1088/ 0967-3334/25/5/014

${ }^{9}$ R. Pinter, R. Schmidt, Impedance Measurement Circuit and Method. U.S. Patent No. 8831898, 2010

URL:http://patft.uspto.gov/netacgi/nphParser?Sect $1=$ PTO1\&Sect2= HITOFF \&d=PALL \& $\mathrm{p}=1 \& \mathrm{u}=\% 2$ Fnetahtm $\%$ 2FPTO $\% 2$ Frrchnum.ht $\mathrm{m} \& \mathrm{r}=1 \& \mathrm{f}=\mathrm{G} \& \mathrm{l}=50 \& \mathrm{~s} 1=8831898 . \mathrm{PN} . \& \mathrm{OS}=\mathrm{PN} / 8831898 \mathrm{RS}=\mathrm{PN} / 88$ 31898

${ }^{10}$ T. Palko, F. Bialokoz, J. Weglarz, Multifrequency device for measurement of the complex electrical bio-impedance - design and application, Proc. of the Engineering in Medicine and Biology Society, 1995 and 14th Conference of the Biomedical Engineering Society of India, An International Meeting, the first regional conference, New Delhi, 1995, doi:10.1109/RCEMBS.1995.508682
${ }^{11}$ Y. Yang, J. Wang, G. Yu, F. Niu, P. He, Design and preliminary evaluation of a portable device for the measurement of bioimpedance spectroscopy, Physiol Meas, 27 (2006) 12, 1293-1310

${ }^{12}$ H. P. Schwan, Electrode polarization impedance and measurements in biological materials, Ann N Y Acad Sci, 148 (1968), 191-209

${ }^{13}$ H. P. Schwan, Linear and nonlinear electrode polarization and biological materials, Ann Biomed Eng, 20 (1992), 269-288

${ }^{14}$ E. Barsoukov, J. R. Macdonald, Impedance spectroscopy: theory, experiment and applications, 2nd ed., John Wiley \& sons, Hoboken, New Jersey 2005

${ }^{15}$ A. J. Bard, L. R. Faulkner, Electrochemical methods: fundamentals and applications, 2nd ed., John Wiley \& sons, New York 2001

${ }^{16}$ J. O’M. Bockris, A. K. N. Reddy, Modern Electrochemistry, vol. 2, Plenum publishing corporation, New York 1970

${ }^{17}$ J. R. Macdonald, Impedance spectroscopy, John Wiley \& sons, New York 1987

${ }^{18}$ T. K. Bera, Bioelectrical impedance methods for noninvasive health monitoring: a review, Journal of Medical Engineering, 2014 (2014), Article ID 381251, 28 pages, doi:10.1155/2014/381251

${ }^{19}$ P. Pečlin, J. Rozman, Alternative paradigm of selective vagus nerve stimulation tested on an isolated porcine vagus nerve, Scientific World Journal, 2014 (2014), 310283, doi:10.1155/2014/310283

${ }^{20}$ A. A. Silverio, A. A. Silverio, A high output impedance current source for wideband bioimpedance spectroscopy using $0.35 \mu \mathrm{M}$ TSMC CMOS technology, International Journal of Engineering and Applied Sciences, 1 (2012) 2, 68-75

${ }^{21}$ E. M. Hudak, J. T. Mortimer, H. B. Martin, Platinum for neural stimulation: voltammetry considerations, J Neural Eng, 7 (2010) 2, 26005, doi:10.1088/1741-2560/7/2/026005

${ }^{22}$ T. A. Anholt, S. Ayal, J. A. Goldberg, Recruitment and blocking properties of the CardioFit stimulation lead, J Neural Eng, 8 (2011) 3, 034004, doi:10.1088/1741-2560/8/3/034004

${ }^{23}$ A. M. Bilgutay, I. M. Bilgutay, F. K. Merkel, C. W. Lillehei, Vagal tuning: a new concept in the treatment of supraventricular arrhythmias, angina pectoris, and heart failure, J Thorac Cardiovasc Surg, 56 (1968), 71-82

${ }^{24}$ C. Heck, S. L. Helmers, C. M. DeGiorgio, Vagus nerve stimulation therapy, epilepsy, and device parameters: scientific basis and recommendations for use, Neurology, 59 (2002), S31-S37

${ }^{25}$ D. M. Labiner, G. L. Ahern, Vagus nerve stimulation therapy in depression and epilepsy: therapeutic parameter settings, Acta Neurol Scand, 115 (2007), 23-33

${ }^{26}$ J. D. Sweeney, D. A. Ksienski, J. T. Mortimer, A nerve cuff technique for selective excitation of peripheral nerve trunk regions, IEEE Trans Biomed Eng, 37 (1990) 7, 706-715

${ }^{27}$ A. Q. Choi, J. K. Cavanaugh, D. M. Durand, Selectivity of multiple-contact nerve cuff electrodes: asimulation analysis, IEEE Trans Biomed Eng, 48 (2001), 165-172

${ }^{28}$ W. Franks, I. Schenker, P. Schmutz, A. Hierlemann, Impedance characterization and modeling of electrodes for biomedical applications, IEEE Trans Biom Eng, 52 (2005) 7, 1295-1302

${ }^{29}$ M. Tykocinski, Y. Duan, B. Tabor, R. S. Cowan, Chronic electrical stimulation of the auditory nerve using high surface area (HiQ) platinum electrodes, Hear Res, 159 (2001) 1-2, 53-68

${ }^{30} \mathrm{D}$. R. Merrill, The electrochemistry of charge injection at the electrode/tissue interface, In: D. Zhou, E. Greenbaum, Implantable Neural Prostheses 2, Springer, New York 2010, 85-138, doi:10.1007/ 978-0-387-98120-8_4

${ }^{31}$ L. A. Geddes, Historical evolution of circuit models for the electrode-electrolyte interface, Ann Biomed Eng, 25 (1997), 1-14 